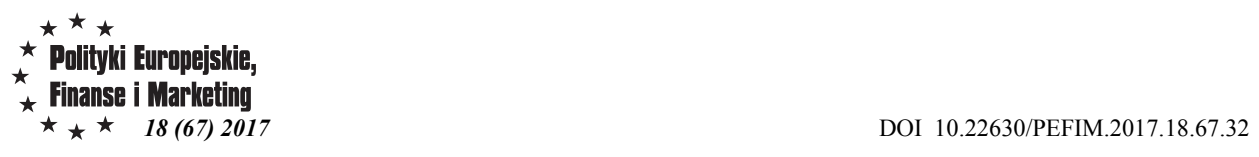

Hanna Sikacz

Uniwersytet Ekonomiczny we Wrockawiu

Przemystaw Wolczek

Uniwersytet Ekonomiczny we Wroctawiu

\title{
Analiza ESG spółek z indeksu RESPECT - podsumowanie badań
}

\section{ESG ANALYSIS OF COMPANIES INCLUDED IN THE RESPECT INDEX - SUMMARY OF RESEARCH}

\begin{abstract}
Niniejsze opracowanie stanowi podsumowanie badań zwiqzanych z analiza ESG spótek wchodzacych $w$ sklad RESPECT Index. Celem artykut jest dokonanie oceny porównawczej informacji pozyskanych $z$ dwóch baz danych: ASSET4 ESG i Thomson Reuters Eikon oraz na podstawie tych informacji przeprowadzenie analizy wyników ESG przedsiębiorstw z indeksu RESPECT. Analiza ma odpowiedzieć na pytanie czy spótki z przedmiotowego indeksu to rzeczywiście podmioty, które $w$ najwyższym stopniu spetniaja wymagania $w$ zakresie zarzadzania czynnikami środowiskowymi, społecznymi i tadu organizacyjnego. Przedstawione $w$ artykule rezultaty badań wskazuja na pewne rozbieżności w wynikach ESG uzyskanych przez spótki. Wyniki ESG pozyskane z bazy ASSET4 ESG sq korzystniejsze dla analizowanych spótek. Należy podkreślić, że kwalifikacja danego przedsiębiorstwa do indeksu spótek społecznie odpowiedzialnych nie powinna budzić żadnych watpliwości. Tymczasem, pomimo różnic wystepujacych w wynikach ESG między analizowanymi bazami, okazato się, że do X edycji indeksu RESPECT dostaty sie spótki z bardzo niskimi wyniki, co rodzi zastrzeżenia do procesu doboru spółek do przedmiotowego indeksu.
\end{abstract}

Słowa kluczowe: czynniki ESG, RESPECT Index, Thomson Reuters Eikon, ASSET4 ESG

This study is a summary of the research related to the ESG analysis of companies included in the RESPECT Index. The aim of the article is to make the comparative assessment of information obtained from two databases: ASSET4 ESG and Thomson Reuters Eikon and on the basis of this information make an analysis of the ESG results of companies from the RESPECT Index. The analysis is intended to answer the question whether the companies in the index are really those who fulfill at the highest level the requirements in the area of environment, social and corporate governance. The results of the research presented in this paper show some divergences in ESG results obtained by companies. The ESG results from the ASSET4 ESG database are more favorable for the companies analyzed. It should be emphasized that the qualification of a given company into the index of socially responsible companies should not raise any doubts. Meanwhile, in spite of the differences in the ESG results between the analyzed databases, it turned out that to the $X$ edition of the RESPECT Index have been qualified companies with very low ESG results, which raises objections to the process of selecting companies to the index. 
Key words: ESG factors, RESPECT Index, Thomson Reuters Eikon, ASSET4 ESG, ESG databases

\section{Wprowadzenie}

Dotarcie do informacji finansowych, dzięki licznym bazom danych, nie sprawia w dzisiejszych czasach już trudności, a uznana na świecie standardowa ocena sytuacji finansowej spółki odbywa się zazwyczaj według określonego schematu (analiza wstępna i analiz wskaźnikowa m.in. płynności, obrotowości, zadłużenia i rentowności). Natomiast w związku z faktem, że raportowanie danych niefinansowych staje się również istotnym elementem sprawozdawczości okresowej, czego przykładem jest chociażby wdrożenie przepisów dyrektywy Parlamentu Europejskiego i Rady 2014/95/UE [Dyrektywa], przypuszcza się, że ocena spółki na podstawie danych niefinansowych nabierze na znaczeniu i także doczeka się określonego schematu.

Dane niefinansowe należy wiązać z kwestiami ochrony środowiska, odpowiedzialności społecznej i ładu organizacyjnego określanymi jako dane ESG (ang. Environmetal, Social, Governance). W najwyższym stopniu wymagania w zakresie ładu informacyjnego i relacji z inwestorami, a przede wszystkim spełniania szeregu wymagań zaliczanych do grupy czynników środowiskowych, społecznych i ładu organizacyjnego powinny spełniać spółki należące do giełdowych indeksów przedsiębiorstw społecznie odpowiedzialnych. Przynależność do takiego indeksu może przynieść przedsiębiorstwu konkretne korzyści. Jak bowiem pokazują wyniki badań przeprowadzonych przez departament doradztwa w zakresie zmian klimatycznych Deutsche Bank [DB Climate Change Advisors 2012] podmioty o wysokim ratingu $\mathrm{CSR}^{2}$ (oceniającym ich sposób zarządzania czynnikami ESG) mają niższy (ex-ante) koszt kapitału. Oznacza to, że rynek postrzega przedsiębiorstwa lepiej zarządzające czynnikami ESG za mniej ryzykowne niż inne i stosownie je za to wynagradza. Co więcej okazało się, że zarządzanie czynnikami ESG jest również pozytywnie skorelowane z wynikami finansowymi spółki. Analizowane prace badawcze w przeważającej większości wykazywały, że przedsiębiorstwa plasujące się wysoko w ratingach CSR osiagają ponadprzeciętne wyniki finansowe, a ich kurs akcji zachowuje się lepiej niż indeksy rynkowe.

Problematyka czynników ESG podejmowana jest przede wszystkim w kontekście odpowiedzialnego inwestowania (ang. Socially Responsible Investing, SRI), analizy ESG spółek, rozwoju zrównoważonego i społecznej odpowiedzialności przedsiębiorstwa oraz raportowania informacji niefinansowych. Działania przedsiębiorstwa w obszarach związanych ze środowiskiem, społeczeństwem i ładem organizacyjnym należy wiązać m.in. z:

- budowaniem wartości przedsiębiorstwa [Domańska-Szaruga B., 2011, s. 141-151],

\footnotetext{
${ }^{1}$ Departament doradztwa w zakresie zmian klimatycznych Deutsche Bank przeprowadził kompleksową analizę badań na temat powiązań między wynikami przedsiębiorstw w zakresie ESG a m.in. kosztem pozyskania przez nie kapitału czy ich wynikami finansowymi. W celu zwiększenia zaufania do wyników przeprowadzonej analizy, wybrano tylko te dokumenty, które spełniły minimalny poziom dyscypliny akademickiej - zostały opublikowane w znanych czasopismach naukowych. Z ponad 100 badań z ostatnich 15 lat, które zostały zidentyfikowane w początkowej fazie, w analizie uwzględniono 56 prac badawczych, a także 2 przeglądy literatury i 4 meta-analizy.

${ }^{2}$ CSR - społeczna odpowiedzialność przedsiębiorstwa (ang. Corporate Social Responsibility).
} 
- budową portfela w ramach inwestycji społecznie odpowiedzialnych [Marcinkowska 2010, s. 124],

- kwestiami związanymi z niższym kosztem kapitału [Bassen i in. 2006],

- lepszym wizerunkiem i zaufaniem do spółki [Sroka 2014, s. 46],

- większą innowacyjnością [Burke, Logsdon 1996, s. 500],

- lepszym zarządzeniem ryzykiem w przedsiębiorstwie w przypadku dodatkowego uwzględniania ryzyk związanych $\mathrm{z}$ wpływem na środowisko czy w obszarze społecznym [Jędrzejka 2014, s. 14],

- redukcją zużycia zasobów [Jędrzejka 2014, s. 14],

- lepszą postawą pracowników wobec przedsiębiorstwa [Knox, Maklan 2004, s. 2529; Burke, Logsdon 1996, s. 500; Maignan, Ferrell 2001, s. 39-40],

- demonstracja zdolności podmiotu do uczestnictwa w konkurencyjnych rynkach [Kaputa 2013, s. 116].

Informowanie interesariuszy o wynikach podejmowanych działań w obszarach ESG świadczy o transparentności raportujących przedsiębiorstw. Z kolei większa przejrzystość spółek pozwala na podejmowanie bardziej racjonalnych decyzji inwestycyjnych [Sroka, 2012, s. 8]. Można zatem spodziewać się, że zapotrzebowanie na dane ESG będzie nadal rosnąć, a bazy $\mathrm{z}$ danymi ESG mogą pomóc inwestorom w podejmowaniu decyzji inwestycyjnych [Ribando J.M., Bonne G. 2010, s. 8].

Biorąc powyższe pod uwagę należy dojść do wniosku, że inwestorzy są coraz bardziej zainteresowani współpracą $\mathrm{z}$ odpowiedzialnymi przedsiębiorstwami. Takie przedsiębiorstwa oprócz dobrych wyników finansowych charakteryzują się przejrzystym sposobem zarządzania, odpowiedzialnym budowaniem wizerunku oraz dbaniem o dobre relacje $\mathrm{z}$ otoczeniem. Dla wielu inwestorów wiarygodność finansowa przedsiębiorstwa jest uzależniona od jego wiarygodności społecznej. Z kolei na wzrost poziomu wiarygodności społecznej przedsiębiorstwa obecnego w obrocie giełdowym pozytywny wpływ powinien mieć udział takiego podmiotu w indeksie spółek społecznie odpowiedzialnych.

W Polsce tego typu indeksem od I edycji w 2009 r. jest RESPECT Index (ang. Responsibility, Ecology, Sustainability, Participation, Environment, Community, Transparency). Proces doboru spółek do tego indeksu uwzględnia m.in. analizę ankiety adresowanej do określonych przedsiębiorstw, której struktura od VII edycji w 2013 r. uwzględnia pytania podzielone na informacje z zakresu ESG. Najbardziej aktualna wersja ankiety (dotycząca XI edycji indeksu) obejmuje 51 pytań, z których dwa pytania z obszaru czynników społecznych są rozbudowane i ostateczna liczba pytań to 53. Wyniki ankiet nie są jednak ogólnie dostępne dla zainteresowanych zewnętrznych interesariuszy. Biorąc pod uwagę tę niedogodność w dostępie do informacji na temat zarządzania czynnikami ESG przez przedsiębiorstwa wchodzące w skład indeksu RESPECT, wydaje się, że uznane na świecie bazy danych, gromadzące informacje $\mathrm{z}$ zakresu zarządzania czynnikami ESG przez przedsiębiorstwa, powinny stać się użytecznymi narzędziami wykorzystywanymi przez naukowców, jak i praktyków (inwestorów, przedsiębiorców, menadżerów, specjalistów) do analizy informacji niefinansowych przedsiębiorstw. Do takich baz danych należy zaliczyć bazę ASSET4 ESG i bazę Thomson Reuters Eikon.

Niniejsze opracowanie stanowi podsumowanie badań, których wyniki szczegółowe zostały przedstawione w trzech publikacjach [zob. Sikacz, Wołczek 2017a, 2017b, 2017c]. Celem artykuł jest dokonanie oceny porównawczej informacji pozyskanych $\mathrm{z}$ dwóch 
wspomnianych baz danych oraz na podstawie tych informacji przeprowadzenie analizy wyników ESG spółek wchodzących w skład indeksu RESPECT. Analiza ta ma odpowiedzieć na pytanie czy spółki z RESPET Index to rzeczywiście podmioty, które w najwyższym stopniu spełniają wymagania $\mathrm{w}$ zakresie zarządzania czynnikami środowiskowymi, społecznymi i ładu organizacyjnego.

\section{ASSET4 ESG vs. Thomson Reuters Eikon - podstawowe informacje o bazach i ocenie ESG}

Porównanie podstawowych informacji o bazach oraz informacji o spółkach według kategorii i obszarów ESG możliwych do pozyskania z baz ASSET4 ESG i Thomson Reuters Eikon znajduje się w tabeli 1 i 2.

Tabela 1. Podstawowe informacje liczbowe o bazach ASSET4 ESG i Thomson Reuters Eikon

\begin{tabular}{|l|c|c|}
\hline \multicolumn{1}{|c|}{ Podstawowe informacje liczbowe o bazach } & $\begin{array}{c}\text { ASSET4 } \\
\text { ESG }\end{array}$ & $\begin{array}{c}\text { Thomson } \\
\text { Reuters Eikon }\end{array}$ \\
\hline Liczba informacji po przetworzeniu danych branych pod uwagę do oceny ESG & $118(122)$ & 178 \\
Liczba KPI (ang. key performacne indicators) & 280 & 70 \\
Liczba danych cząstkowych o przedsiębiorstwie & 750 & 400 \\
Liczba przedsiębiorstw w bazie & 4300 & 6000 \\
\hline
\end{tabular}

Źródło: opracowanie własne.

Jak wskazują przedstawione $\mathrm{w}$ tabeli informacje dotyczące baz $\mathrm{z}$ wynikami ESG więcej danych o przedsiębiorstwie zebranych jest $\mathrm{w}$ bazie ASSET4 ESG - 750 danych $\mathrm{w}$ porównaniu z 400 danymi zebranymi w bazie Thomson Reuters Eikon. Na podstawie tych danych zostaje wygenerowanych $280 \mathrm{KPI}$ (ang. key performacne indicators) w bazie ASSET4 ESG i 70 KPI w kolejnej bazie. Ostatecznie do oceny ESG przedsiębiorstw branych jest pod uwagę 118 (122) informacji w bazie ASSET4 ESG i 178 informacji w bazie Thomson Reuters Eikon.

Tabela 2. Liczba informacji o spółkach według kategorii i obszarów ESG w bazach ASSET4 ESG i Thomson Reuters Eikon

\begin{tabular}{|c|c|c|c|c|c|c|}
\hline Obszar & $\begin{array}{l}\text { Kategoria według bazy } \\
\text { ASSET4 ESG }\end{array}$ & \multicolumn{2}{|c|}{$\begin{array}{l}\text { Liczba } \\
\text { informacji }\end{array}$} & $\begin{array}{l}\text { Kategoria według bazy } \\
\text { Thomson Reuters Eikon }\end{array}$ & \multicolumn{2}{|c|}{$\begin{array}{l}\text { Liczba } \\
\text { informacji }\end{array}$} \\
\hline Środowisko & $\begin{array}{l}\text { Redukcja emisji } \\
\text { Zużycie zasobów } \\
\text { Innowacje produktowe }\end{array}$ & $\begin{array}{c}22 \\
19 \\
5\end{array}$ & $\begin{array}{l}46+1 \\
=47\end{array}$ & $\begin{array}{l}\text { Emisje } \\
\text { Zużycie zasobów } \\
\text { Innowacja }\end{array}$ & $\begin{array}{l}22 \\
20 \\
19\end{array}$ & 61 \\
\hline Społeczeństwo & $\begin{array}{l}\text { Jakość zatrudnienia } \\
\text { Zdrowie i bezpieczeństwo } \\
\text { Szkolenie i rozwój } \\
\text { Różnorodność } \\
\text { Prawa człowieka } \\
\text { Społeczność } \\
\text { Odpowiedzialność za } \\
\text { produkt }\end{array}$ & $\begin{array}{l}10 \\
5 \\
5 \\
6 \\
3 \\
6 \\
4\end{array}$ & $\begin{array}{l}39+1 \\
=40\end{array}$ & $\begin{array}{l}\text { Pracownicy } \\
\text { Prawa człowieka } \\
\text { Społeczność } \\
\begin{array}{l}\text { Odpowiedzialność za } \\
\text { produkt }\end{array}\end{array}$ & 14 & 63 \\
\hline
\end{tabular}




\begin{tabular}{|l|l|c|c|l|c|c|}
\hline & Struktura Zarządu & 8 & & Zarządzanie & 34 & \\
Ład & Funkcja zarządu & 9 & & & & \\
organizacyjny & Polityka rekompensaty & 6 & $33+1$ & & & \\
& Prawa akcjonariuszy & 5 & & Akcjonariusze & 12 & \\
& Wizja i strategia & 5 & & Strategia CSR & 8 & \\
\hline Ekonomia & Ekonomia & & 1 & & & \\
\hline Razem & 16 kategorii & 118 & 122 & 10 kategorii & 178 & 178 \\
\hline
\end{tabular}

Obszary z zakresu ESG podzielone są na 16 kategorii w pierwszej z baza, natomiast w drugiej bazie na 10 kategorii. Pełna zbieżność nazw tych kategorii występuje w przypadku obszaru dotyczącego środowiska, $\mathrm{z}$ pewną jednak istotną różnica dotycząca liczby zbieranych informacji z kategorii innowacji. Więcej uwagi poświęcone jest tej kategorii w bazie Thomson Reuters Eikon.

W obszarze dotyczącym społeczeństwa nazwy trzech kategorii (,prawa człowieka”, „społeczność” i „odpowiedzialność za produkt”) są identyczne. Należy jednak zwrócić uwagę na fakt, że $\mathrm{w}$ każdej $\mathrm{z}$ tych trzech kategorii więcej informacji ( $\mathrm{w}$ sumie 34) analizowanych jest w bazie Thomson Reuters Eikon niż w bazie ASSET4 ESG (w sumie 13). Różnica między porównywanymi bazami występuje odnośnie pozostałych kategorii. W bazie Thomson Reuter Eikon występuje kategoria „pracownicy” z 29 informacjami, natomiast w drugiej bazie możemy wskazać cztery kategorie: ,jakość zatrudnienia”, „zdrowie i bezpieczeństwo”, „,szkolenia i rozwój” oraz „różnorodność”, które w sumie zawieraja 26 informacji. Szczegółowa analiza struktury kategorii ,pracownicy” z bazy Thompson Reuter Eikon pozwala stwierdzić, że w jej skład wchodzą zagadnienia, które ujęte są we wspomnianych czterech kategoriach $\mathrm{z}$ drugiej bazy.

Z kolei jeśli chodzi o obszar zajmujący się kwestiami ładu organizacyjnego, należy zauważyć, że nazwy kategorii w obu bazach nie pokrywają się. Jednak pogłębiona analiza danych zawartych w obu bazach pozwala stwierdzić, że:

- kategoria „strategia CSR” z bazy Thompson Reuter Eikon zawiera cztery z pięciu informacji z kategorii „wizja i strategia” z bazy ASSET4 ESG,

- kategoria „akcjonariusze” zawiera cztery z pięciu informacji z kategorii „prawa akcjonariuszy",

- kategoria „zarządzanie” zawiera wszystkie informacje z kategorii „struktura zarządu”, osiem z dziewięciu informacji z kategorii „funkcja zarządu” oraz cztery z sześciu informacji z kategorii ,polityka rekompensaty”.

Porównując obie bazy, z punktu widzenia podziału na kategorie i zawarte $\mathrm{w}$ nich informacje, można dojść do wniosku, że struktura bazy Thomson Reuter Eikon pokrywa się w dużej mierze z bazą ASSET4 ESG. Należy przy tym zauważyć, że pierwsza z baz gromadzi więcej (w sumie o 66) szczegółowych informacji ESG o przedsiębiorstwach niż druga baza. Ponadto w pierwszej bazie zdecydowanie więcej jest informacji o różnego rodzaju politykach obowiązujących w przedsiębiorstwie. Baza Thomson Reuters Eikon gromadzi informacje $\mathrm{w}$ sumie o 40 dokumentach typu polityka (w tym: obszar „środowisko" - 6 polityk, ,społeczeństwo" - 20; ład organizacyjny - 14) a baza ASSET4 ESG tylko o 13 (w tym: ,środowisko” - 3; ,społeczeństwo” - 7; „,ad organizacyjny” - 3). 
Na rysunku 1 przedstawiono udziały liczby informacji z poszczególnych obszarów ESG w ogólnej liczbie przetworzonych informacji, branych pod uwage wobu analizowanych bazach danych, do oceny ESG przedsiębiorstw.

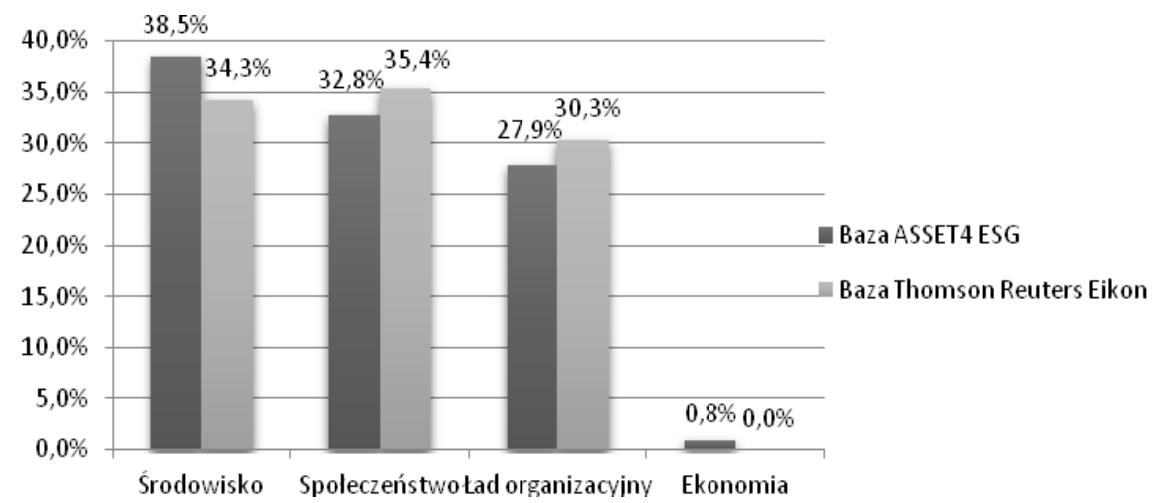

Rysunek 1. Struktura informacji według danych ESG w bazach ASSET4 ESG i Thomson Reuters Eikon Źródło: opracowanie własne.

Baza ASSET4 ESG gromadząc dane ESG kładzie duży nacisk na aspekty środowiskowe, ponieważ udział tych informacji w ogólnej liczbie wszystkich danych ESG to $38,5 \%$. W dalszej kolejności są informacje dotyczące społeczeństwa $\mathrm{z}$ udziałem wynoszacym 32,8\% iadu organizacyjnego $\mathrm{z}$ udziałem 27,9\%. Udział informacji ekonomicznych to jedynie $0,8 \%$. Należy przy tym pamiętać, że obszar ekonomiczny mierzy zdolność firmy do generowania trwałego wzrostu i wysokiego zwrotu z inwestycji dzięki efektywnemu wykorzystaniu wszystkich zasobów. Jest to odzwierciedlenie ogólnej kondycji finansowej firmy i jej zdolności do generowania długoterminowej wartości dla akcjonariuszy dzięki zastosowaniu najlepszych praktyk zarządzania. $\mathrm{Z}$ kolei $\mathrm{w}$ bazie Thomson Reuters dominują informacje dotyczące społeczeństwa (35,4\% udziału). Udział informacji środowiskowych jest porównywalny (34,3\%). Najmniejszy udział, podobnie jak w bazie ASSET4 ESG, stanowią informacje związane z ładem organizacyjnym (30,3\%).

Odnosząc się do wyników oceny ESG przedsiębiorstw, jakie można pozyskać z obu analizowanych baz, należy stwierdzić, że wyniki te są trudno porównywalne. Trudność bierze się stąd, że wyniki ESG przedsiębiorstw w bazie ASSET4 ESG są podawane jako wartości procentowe. $Z$ kolei $\mathrm{w}$ bazie Thomson Reuters Eikon wyniki ESG przedsiębiorstw są prezentowane za pomocą oznaczeń w skali od D- do A+ (D-, D, D+, C, C, C+, B-, B, B+, A-, A, A+) w zależności od tego, w jakim przedziale punktowym znalazła się wartość wskaźnika wykorzystanego do oceny ESG dane przedsiębiorstwa.

Podsumowując można stwierdzić, że przydatność obu baz, do oceny ESG przedsiębiorstw, ze względu na liczbę gromadzonych informacji, jest duża. $Z$ drugiej strony problem dla osób zainteresowanych problematyką ESG, przedsiębiorstwami społecznie odpowiedzialnymi, indeksami giełdowymi spółek odpowiedzialnych społecznie czy też inwestycjami typu SRI, może stanowić brak możliwości bezpośredniego porównania wyników ESG dla danego przedsiębiorstwa, uzyskanych z obu analizowanych baz. 


\section{Metoda i wyniki badań}

W skład X edycji indeksu RESPECT wchodzą obecnie 24 spółki ${ }^{3}$. Dane uzyskane z bazy ASSET4 ESG dotyczą jedenastu z tych spółek, natomiast $\mathrm{z}$ bazy Thomson Reuters Eikon piętnastu. Brak w bazach informacji ESG o pozostałych spółkach $\mathrm{z}$ indeksu uniemożliwia dokonanie oceny porównawczej dla wszystkich spółek. W związku z powyższym wyniki badań obejmują 11 spółek z RESPECT Index. Poszczególne etapy badań obejmowały więc: zebranie danych ESG spółek $z$ indeksu RESPECT z bazy ASSET4 ESG i Thomson Reuters Eikon, przygotowanie listy spółek możliwych do porównania (warunek przyjęcia do badań - dane dla spółki w obu bazach), zapewnienie porównywalności wyników ESG pozyskanych z dwóch baz.

Na podstawie zaprezentowanych w tabeli 3 wyników ESG spółek z RESPECT Index pozyskanych $\mathrm{z}$ baz ASSET4 ESG i Thomson Reuters Eikon można dokonać oceny porównawczej spółek, ale można także porównać między sobą dane z tych baz dla określonej spółki. Wynik ESG Score na podstawie bazy Thomson Reuters Eikon nie jest wartością liczbową wyrażoną w procentach, tylko oznaczony jest odpowiednim symbolem. Dany symbol oznacza odpowiedni przedział uzyskanych wyników ${ }^{4}$. W związku z powyższym, aby możliwe było porównanie wyników ESG spółek uzyskanych z dwóch baz, odpowiednie symbole zamieniono na przedziały wyników, a następnie uśredniono wartości z danego przedziału, w ten sposób uzyskując wynik ESG dla danej spółki.

Tabela 3. Wyniki ESG spółek z RESPECT Index na podstawie bazy ASSET4 ESG i Thomson Reuters Eikon

\begin{tabular}{|c|c|c|c|c|}
\hline Spółka & $\begin{array}{l}\text { ASSET4 } \\
\text { ESG }\end{array}$ & \begin{tabular}{|c|} 
ESG Score \\
(Thomson Reuters \\
Eikon)
\end{tabular} & $\begin{array}{c}\text { Srednia wartość ESG } \\
\text { Score (Thomson } \\
\text { Reuters Eikon) }\end{array}$ & $\begin{array}{c}\text { Różnica w wartościach } \\
\text { wskaźników między } \\
\text { bazami }\end{array}$ \\
\hline $\begin{array}{l}\text { Powszechny Zakład } \\
\text { Ubezpieczeń S.A. }\end{array}$ & $62 \%$ & $41,7 \%-50,0 \%$ & $45,9 \%$ & 16,1 p.p. \\
\hline $\begin{array}{l}\text { Polski Koncern Naftowy } \\
\text { Orlen S.A. }\end{array}$ & $86 \%$ & $66,7 \%-75,0 \%$ & $70,9 \%$ & 15,1 p.p. \\
\hline Bank Pekao S.A. & $70 \%$ & $58,3 \%-66,7 \%$ & $62,5 \%$ & 7,5 p.p. \\
\hline $\begin{array}{l}\text { Polskie Górnictwo Naftowe } \\
\text { i Gazownictwo S.A. }\end{array}$ & $50 \%$ & $33,3 \%-41,7 \%$ & $37,5 \%$ & 12,5 p.p. \\
\hline Bank Zachodni WBK S.A. & $83 \%$ & $50,0 \%-58,3 \%$ & $54,2 \%$ & 28,8 p.p. \\
\hline KGHM Polska Miedź S.A. & $73 \%$ & $58,3 \%-66,7 \%$ & $62,5 \%$ & 10,5 p.p. \\
\hline $\begin{array}{l}\text { Polska Grupa Energetyczna } \\
\text { S.A. }\end{array}$ & $40 \%$ & $25,0 \%-33,3 \%$ & $29,2 \%$ & 10,8 p.p. \\
\hline ING Bank Śląski S.A. & $81 \%$ & $50,0 \%-58,3 \%$ & $54,2 \%$ & 26,8 p.p. \\
\hline Bank Millennium S.A. & $80 \%$ & $58,3 \%-66,7 \%$ & $62,5 \%$ & 17,5 p.p. \\
\hline Tauron Polska Energia S.A. & $30 \%$ & $16,7 \%-25,0 \%$ & $20,9 \%$ & 9,1 p.p. \\
\hline $\begin{array}{l}\text { Bank Handlowy w } \\
\text { Warszawie S.A. }\end{array}$ & $61 \%$ & $50,0 \%-58,3 \%$ & $54,2 \%$ & 6,8 p.p. \\
\hline
\end{tabular}

Źródło: opracowanie własne.

\footnotetext{
${ }^{3}$ Stan na 16.08.2017 r. Obecny skład indeksu został ogłoszony 14.12.2016 r. Pierwotnie indeks liczył 25 spółek, jednak z dniem 08.06.2017 r. decyzją Zarządu GPW obrót akcjami spółki Pelion S.A. został zawieszony.

${ }^{4}$ Przedziały wyników w zależności od symbolu są następujące: D-: $0.0<=$ wynik $<=0.0833$; D: $0.0833<$ wynik $<=0.1666$; D+: $0.1666<$ wynik <= 0.2500; C-: $0.2500<$ wynik <=0.3333; C: $0.3333<$ wynik <=0.4166; C+: $0.4166<$ wynik $<=0.5000$; B-: $0.5000<$ wynik $<=0.5833$; B: $0.5833<$ wynik $<=0.6666$; B+: $0.6666<$ wynik $<=$ 0.7500 ; A-: $0.7500<$ wynik $<=0.8333$; A: $0.8333<$ wynik $<=0.9166$; A+: $0.9166<$ wynik $<=1$.
} 
Wyniki ESG spółek z indeksu RESPECT na podstawie bazy ASSET4 ESG kształtują się w przedziale od 30\% do 86\%, natomiast na podstawie bazy Thomson Reuters Eikon od $20,9 \%$ do $70,9 \%$. Średni wynik ESG dla spółek z pierwszej wymienionej bazy to $65,1 \%$, natomiast dla drugiej bazy - 50,4\%. Średnia różnica w wartościach wskaźników między bazami to 14,7 punktów procentowych (p.p.). Mediana dla przedstawionych wyników to $70 \%$ w przypadku bazy ASSET4 ESG i 54,2\% w przypadku bazy Thomson Reuters Eikon. Dla wszystkich jedenastu analizowanych spółek wyniki ESG w bazie ASSET4 ESG są lepsze niż w drugiej bazie, a największa różnica dotyczy Banku Zachodniego WBK S.A. i wynosi 28,8 p.p.

W przypadku bazy Thomson Reuters Eikon żadna ze spółek nie uzyskuje lepszego wyniku od $71 \%$, natomiast wyniki wyższe od tej wartości na podstawie bazy ASSET4 ESG uzyskuje pięć spółek. Wartość wskaźnika równą bądź niższą 50\% w przypadku obu baz uzyskują takie spółki jak: Tauron Polska Energia S.A., Polska Grupa Energetyczna S.A. oraz Polskie Górnictwo Naftowe i Gazownictwo S.A. W przypadku bazy Thomson Reuters Eikon taki wynik uzyskuje jeszcze jedna ze spółek (Powszechny Zakład Ubezpieczeń S.A.).

W przypadku tylko trzech spółek wyniki ESG uzyskane z obu baz są do siebie zbliżone (różnica między wynikami wynosi maksymalnie do 10 p.p). Te spółki to: Bank Handlowy w Warszawie S.A. (różnica - 6,8 p.p.), Bank Pekao S.A. (7,5 p.p.), Tauron Polska Energia S.A. (9,1 p.p.).

Największe różnice wyników ESG występujące w obu bazach dotyczą dwóch spółek: Banku Zachodniego WBK S.A. (różnica - 28,8 p.p.) oraz ING Banku Śląskiego S.A. (26,8 p.p.). Pogłębiona analiza danych trzech obszarów ESG dla tych spółek pozwala stwierdzić, że na te istotne różnice w wynikach największy wpływ miała ocena w obszarze „społeczeństwo”. W bazie ASSET4 ESG spółka Bank Zachodni WBK S.A. uzyskała w tym obszarze wynik na poziomie $78 \%$, a spółka ING Bank Śląski S.A. na poziomie $82 \%$. Jednak w bazie Thomson Reuter Eikon obie spółki w tym obszarze otrzymały ocenę B-, czyli ich wyniki kształtował się na poziomie 54,2\% uśrednionej wartości.

Podsumowując uzyskane wyniki można wskazać tylko na jedną spółkę, która według obu baz uzyskuje wysokie wyniki ESG (powyżej 70\%), a jest to Polski Koncern Naftowy Orlen S.A. Z kolei wynik ESG powyżej $60 \% \mathrm{w}$ obu bazach uzyskały takie spółki jak: Bank Pekao S.A., KGHM Polska Miedź S.A., Bank Millennium S.A. Kolejne trzy spółki: Bank Zachodni WBK S.A., ING Bank Śląski S.A. oraz Bank Handlowy w Warszawie, uzyskały w obu bazach wynik ESG powyżej 50\%. Powszechny Zakład Ubezpieczeń S.A. w bazie ASSET4 ESG uzyskał wynik powyżej 60\%, a w drugiej bazie poniżej 50\%. Pozostałe przedsiębiorstwa w obu analizowanych bazach uzyskały wynik ESG równy $50 \%$ bądź niższy.

Przyjmując zatem słuszne założenie, że do giełdowego indeksu spółek odpowiedzialnych, za jaki uchodzi RESPECT Index, powinny kwalifikować się przedsiębiorstwa, które w najwyższym stopniu wypełniają szereg wymagań zaliczanych do grupy czynników środowiskowych, społecznej odpowiedzialności i ładu organizacyjnego, można mieć wątpliwości co do procedury selekcji tych spółek do indeksu. Opierając się bowiem na danych pozyskanych z bazy ASSET4 ESG i przyjmując wynik 75\% za dolną granicę, której przekroczenie uprawnia przedsiębiorstwo do wejścia w skład indeksu RESPECT, należy stwierdzić, że z 11 analizowanych spółek tylko cztery powinny znaleźć się w tym indeksie. Są to: Polski Koncern Naftowy Orlen S.A. (wynik ESG - 86\%), Bank 
Zachodni WBK S.A. (83\%), ING Bank Śląski S.A. (81\%) oraz Bank Millenium S.A. $(80 \%)$. Z kolei opierając się na danych pozyskanych z bazy Thomson Reuter Eikon i przyjmując wynik A-, jako minimum uprawniające do wejścia w skład indeksu RESPECT, należy stwierdzić, że żadna z analizowanych spółek nie powinna znaleźć się w obecnej X edycji indeksu.

\section{Podsumowanie i wnioski}

Wzrost znaczenia uwzględniania w funkcjonowaniu przedsiębiorstw kwestii ESG i informowania otoczenia o działaniach i wynikach osiaganych w ramach tych obszarów skłania interesariuszy do poszukiwania $\mathrm{i}$ analizowania informacji niefinansowych $\mathrm{o}$ intersujących ich podmiotach. Z pomocą przychodzą renomowani światowi dostawcy informacji, od których można pozyskiwać dane (już nie tylko finansowe) przydatne w podejmowaniu decyzji dotyczących np. inwestowania czy nawiązania współpracy.

Przedstawione $\mathrm{w}$ niniejszym opracowaniu wyniki badań wskazują na pewne rozbieżności w wynikach ESG uzyskanych przez spółki wchodzące w skład indeksu RESPECT na podstawie przedmiotowych baz ASSET4 ESG i Thomson Reuters Eikon. Można wyciagnąć wniosek, że oceny uzyskane na podstawie bazy ASSET4 ESG są korzystniejsze dla spółek. Tym niemniej, mając na uwadze fakt, że kwalifikacja danego przedsiębiorstwa do giełdowego indeksu spółek społecznie odpowiedzialnych nie powinna budzić żadnych wątpliwości, można mieć zastrzeżenia do składu $\mathrm{X}$ edycji indeksu RESPECT. Należy stwierdzić, że Mimo różnic występujących między bazami, do indeksu powinno dobierać się spółki, które uzyskują wysokie wyniki ESG. Tymczasem okazuje się, że do przedmiotowego indeksu zakwalifikowały się spółki z bardzo niskimi ocenami ESG. Taki stan rzeczy rodzi uprawnione wątpliwości co do procedury doboru spółek do indeksu RESPECT i sugeruje dokonanie jej weryfikacji pod kątem uwzględniania wyników ESG przedsiębiorstw w tej procedurze.

\section{Literatura}

Bassen A., Meyer K., Schlange J., The influence of corporate responsibility on the cost of capital, 2006, http://ssrn.com/abstract=984406 (24.08.2017).

Burke L., Logsdon J.M., How corporate social responsibility pays off, Long Range Planning, vol. 29, 1996, s. 495-502.

DB Climate Change Advisors, Sustainable Investing. Establishing Long-Term Value and Performance, Deutsche Bank AG, Frankfurt am Main, 2012, https://www.db.com/cr/en/docs/Sustainable_Investing_2012.pdf (25.08.2017).

Domańska-Szaruga B., Rola czynników ESG w budowaniu wartości przedsiębiorstwa, Współczesne Zarządzanie / Contemporary Management Quarterly nr 4, 2011, s. 141-151.

Dyrektywa Parlamentu Europejskiego i Rady 2014/95/UE z 22 października 2014 r. zmieniająca dyrektywe 2013/34/UE w odniesieniu do ujawniania informacji niefinansowych i informacji dotyczących różnorodności przez niektóre duże jednostki oraz grupy (Dz. Urz. UE L 330 z 15.11.2014, str. 1 oraz Dz. Urz. UE L 207 z 04.08.2015, str. 1)

Jędrzejka D., Ujawnienia ESG polskich spótek giełdowych w świetle wyników badań, Studia Ekonomiczne, nr 186 cz. 2, 2014, s. 13-26

Kaputa J., Raportowanie zrównoważonego rozwoju jako wyzwanie dla przedsiębiorstw XXI wieku, Zarządzanie i Finanse, 2013, s. 113-127.

Knox S., Maklan S., Corporate Social Responsibility: moving beyond investment towards measuring outcomes, European Management Journal, vol. 22, no. 5, 2004, s. 23-35.

Maignan I., Ferrell O.C., Antecedents and benefits of corporate citizenship: an investigation of french businesses, Journal of Business Research, vol. 51, 2001, s. 37-51. 
Marcinkowska M., Odpowiedzialne przedsiębiorstwo na rynku kapitałowym - czyli o giełdowych indeksach zrównoważonego rozwoju, w: J. Duraj (red.), Przedsiębiorstwo na rynku kapitałowym, Wyd. UŁ, Łódź, 2010, s. 123-144.

Ribando J.M., G. Bonne G., A new quality factor: finding alpha with ASSET4 ESG data, Thomson Reuter, $\begin{array}{lll}\text { Starmine } & \text { Nesearch } \quad 2010 \text {, }\end{array}$ http://citeseerx.ist.psu.edu/viewdoc/download?doi=10.1.1.429.577\&rep=rep1\&type=pdf (24.08.2017).

Sikacz H., Wołczek P., Analysis and Evaluation of the RESPECT Index functioning, artykuł przyjęty do recencji w Pracach Naukowych Uniwersytetu Ekonomicznego we Wrocławiu, 2017a

Sikacz H., Wołczek P., Analiza ESG spótek z indeksu RESPECT na podstawie bazy ASSET4 ESG, artykuł po pozytywnych recenzjach oczekuje na publikację w Zeszytach Naukowych Szkoły Głównej Gospodarstwa Wiejskiego w Warszawie, Polityki Europejskie, Finanse i Marketing, 2017b

Sikacz H., Wołczek P., ESG analysis of companies included in the RESPECT index based on Thomson Reuters EIKON database, artykuł przyjęty do recencji w Pracach Naukowych Uniwersytetu Ekonomicznego we Wrocławiu 2017c

Sroka R. (red.), Analiza ESG spółek w Polsce, Stowarzyszenie Emitentów Giełdowych, Warszawa, 2012.

Sroka R. (red.), Analiza ESG spółek w Polsce, Stowarzyszenie Emitentów Giełdowych, Warszawa, 2014.

Thomson Reuters, ASSET4 ESG Data, 2012,

https://www.thomsonreuters.com/content/dam/openweb/documents/pdf/tr-com-financial/fact-sheet/esg-datafact-sheet.pdf (24.08.2017).

Thomson Reuters, Thomson Reuters ESG Scores For Public Companies, Thomson Reuter ESG Score Data fact sheet, 2017a, https://financial.thomsonreuters.com/content/dam/openweb/documents/pdf/financial/esg-scoresfactsheet.pdf (25.08.2017).

Thomson Reuters, Thomson Reuters ESG Scores, Methodology, 2017b,

https://financial.thomsonreuters.com/content/dam/openweb/documents/pdf/financial/esg-scoresmethodology.pdf (25.08.2017).

\section{Abstract}

This study is a summary of the research related to the ESG analysis of companies included in the RESPECT Index. The aim of the article is to make the comparative assessment of information obtained from two databases: ASSET4 ESG and Thomson Reuters Eikon and on the basis of this information make an analysis of the ESG results of companies from the RESPECT Index. The analysis is intended to answer the question whether the companies in the index are really those who fulfill at the highest level the requirements in the area of environment, social and corporate governance. The results of the research presented in this paper show some divergences in ESG results obtained by companies. The ESG results from the ASSET4 ESG database are more favorable for the companies analyzed. It should be emphasized that the qualification of a given company into the index of socially responsible companies should not raise any doubts. Meanwhile, in spite of the differences in the ESG results between the analyzed databases, it turned out that to the $X$ edition of the RESPECT Index have been qualified companies with very low ESG results, which raises objections to the process of selecting companies to the index.

Keywords: ESG factors, RESPECT Index, Thomson Reuters Eikon, ASSET4 ESG, ESG databases 
Informacja o autorach:

\section{Dr inż. Hanna Sikacz}

Uniwersytet Ekonomiczny we Wrocławiu

Wydział Inżynieryjno-Ekonomiczny

Katedra Pracy i Kapitału

e-mail: hanna.sikacz@ue.wroc.pl

\section{Dr Przemyslaw Wołczek}

Uniwersytet Ekonomiczny we Wrocławiu

Wydział Nauk Ekonomicznych

Katedra Zarządzania Strategicznego

e-mail: przemyslaw.wolczek@ue.wroc.pl 